\title{
The Concept of Water Law in the Polish Legal System
}

\author{
Koncepcja prawa wodnego \\ w polskim systemie prawnym
}

\author{
http://dx.doi.org/10.12775/PYEL.2016.002
}

\begin{abstract}
"Water law" has become a standard term in both the Polish language of the law and the Polish legal language. It is used by both the legislator alone, as well as in case law and legal doctrine ${ }^{1}$. However, the term is not used and interpreted unambiguously, which makes it difficult to determine the context in which the term is used and what it means at the specific time. It significantly determines the analysis of the concept
\end{abstract}

Professor doctor habilitated in Environmental Protection Law, Professor of the Kazimierz Wielki University in Bydgoszcz, Head of the Chair of Environmental Protection Law at Faculty of Law and Administration of Nicolaus Copernicus University in Torun, Legal Adviser.

1 K. Szuma, Prawo wodne w systemie prawa ochrony środowiska, part 1 - Prawo i Środowisko 2011, No. 1, p. 70-79, part 2 - Prawo i Środowisko 2011, No. 2, p. 68-83. 


\section{Bartosz Rakoczy}

of water law itself, whereas the scope of the analysis depends on the understanding of the term "water law".

\section{Keywords:}

Water law.

\section{Streszczenie}

"Prawo wodne" stało się podstawowym terminem zarówno w polskim języku prawnym, jak i prawniczym. Jest on stosowany zarówno przez ustawodawcę, jak i w orzecznictwie i doktrynie.Jednakże termin ten nie jest stosowany i interpretowany jednoznacznie, co sprawia, że trudno jest określić kontekst, w którym termin ten został użyty i co on oznacza w określonym czasie. Znacząco determinuje to określa analizę pojęcia samego prawa wodnego, podczas gdy zakres analizy zależy od rozumienia pojęcia „prawa wodnego”.

\section{Słowa kluczowe:}

Prawo wodne.

R. Paczuski studying the term "environmental protection law" has identified as many as six different meanings. He has mentioned normative, instrumental, didactic, scientific and cognitive, informative meaning, and finally, the meaning determining the name of the legislative act ${ }^{2}$. Only this random recital shows that the term "environmental protection law" has multiple meanings. It is identical with the term "water law" which can be used exactly in the same manner. In normative terms, it means all legislative norms governing management and protection of waters, in compliance with the principle of sustainable development and regulating the issues of ownership of waters. In this respect, water law means a comprehensive branch of law within which separate legislative rules can be identified ${ }^{3}$. J. Rotko has presented an interesting concept proposing that all of such

2 R. Paczuski, Ocbrona środowiska. Zarys wyktadu, Bydgoszcz 2008, p. 101

3 B. Rakoczy, Wprowadzenie do prawa wodnego, in: Wybrane problemy prawa wodnego, B. Rakoczy (ed.), Warszawa 2011, p. 15 - 36. 
legislative norms should be termed as "water management law" "At the same time, he has identified the rules of water management law ${ }^{5}$.

In instrumental terms, water law means all the tools available under water management and protection policy. In this case, the starting point is adopting a somewhat justified assumption that law is an instrument for carrying out specific policy.

In didactic terms water law means an independent didactic unit ${ }^{6}$, covering the issues of water management and protection as a whole, and separately. At the same time, it should be emphasized that this is a juridical rather than hydrological, natural, sozological or ecological approach.

In scientific and cognitive terms, water law means a separate and autonomous area of research in legal sciences ${ }^{7}$.

On the other hand, according to the informative approach, water law means a term of scientific information concerning the achievements of domestic and foreign legislation regarding management and protection of waters ${ }^{8}$.

Finally, in terms of defining the name of a legal act, water law means a title of a legal act of 18 July 2001 - Water Law'.

However, the analysis of the concept cannot refer to all the ways in which the term water law can be interpreted. The instrumental approach should be subject to analysis from the point of view of political sciences, whereas the didactic approach should be analysed along with law teaching methods. The informative approach is a matter of scientific information. Hence, the analysis of the concept can only refer to the term "water law" as used in the normative, scientific and cognitive sense, and to the approach defining the name (title) of a legal act.

Thus, two directions of research can be identified in the concept of water law (Water Law) - a narrow, and a broad one. In the broad conceptual

4 J. Rotko, Podstawy prawne gospodarki wodnej, Wrocław 2006.

5 Op. cit., p. 16-23.

6 After R. Paczuski, Ochrona..., p. 102.

7 The proof of such treatment is provided e.g. by J. Rotko, Ramowa dyrektywa wodna. Analiza prawna, Poznań 2013.

8 After R. Paczuski, Ochrona..., p. 103. What is interesting such treatment of water law was not approved by the Authors: M. Górski, J. Stelmasiak (eds) in Wielka Encyklopedia Prawa, vol. VI Prawo ochrony środowiska, Warszawa 2014, although, e.g. the term "geological and mining law" was used in such a sense.

9 Journal of Laws of 2015 item 469, with further amendments. 


\section{Bartosz Rakoczy}

approach water law means a comprehensive branch of law ${ }^{10}$. On the other hand, in the narrow conceptual approach Water Law (capitalised) denotes a legal act.

Further analysis will refer to both conceptual approaches.

Water law in a narrow understanding denotes, as indicated above, the title of a legislative act. According to the same approach, the proof of concept is in fact the test of the legislative act, its taxonomy, principles and issues governed by such an act.

The analysis of the act Water Law indicates that it governs water management in general according to the principle of sustainable development, and in particular shaping and protecting water resources, using waters and managing water resources. It also regulates the ownership of waters and water-covered land, as well as the rules of managing such assets with reference to the State Treasury's property. The reference literature mentions that article 1 of the Water Law determines the subject of the regulation as water management, including the shaping and protection of water resources, use of waters and management of water resources. Whereas, it must be emphasized, that it is only an enumeration of the essential elements of the Water Law ${ }^{11}$.

Thus, the concept of water law in a narrow understanding mainly focuses on shaping and protecting water resources, water use and managing water resources. However, the list is not complete, although without any doubt it includes the most important elements.

In my evaluation, within the narrow concept of water law, ownership of water, land under water and water-covered land requires a separate treatment. In fact, these issues can be classified as related to shaping of water resources but with regard to specific circumstances referred to below, a separate treatment of such issues is fully justified.

First, it must be indicated that the ownership of water is governed comprehensively and separately in the Water Law and, which is significant as it is treated separately from the concept of ownership as defined by civil law. This separation from the civilist approach necessitated exclusive and

10 Such an approach proposes an interesting concept of forest law - see e.g. Polskie prawo leśne, A. Habuda (ed.), Warszawa 2016.

11 W. Radecki, in: Prawo wodne. Komentarz, J. Rotko (ed.), Wrocław 2002, p. 12. 
comprehensive regulation of the ownership in a single legislative act Water $\mathrm{Law}^{12}$.

Ownership of water is given a separate treatment with regard to the fact that water in terms of water law is not separate from nature. Thus, water cannot be considered a thing pursuant to article 45 of the Polish Civil Code reading: "Only tangible objects shall be considered things within the meaning of the present Code".

Hence, specific characteristics of water require that the lawmaker developes a separate model of ownership referring to waters ${ }^{13}$. What is significant, the application of the concept of ownership with reference to water is also characterised by the fact that it makes it possible to accumulate all rights of the owners of waters in a single concept instead of giving a separate treatment to such rights ${ }^{14}$. In addition, within the concept of ownership of waters, the obligations of the owner of waters can be covered by a single legal institution. The traditional civilist approach to ownership in the Polish law disregards the obligations of the owner. On the other hand, the Water Law gives an extensive treatment to both the obligations and the rights.

Finally, ownership of waters is closely connected with the issue of water-covered land and land under waters. The Polish law has not adopted a uniformed model rooted in the Roman law according to which the owner of waters is also the owner of land under such waters. In fact, this rule is known to the Polish lawmaker but only with reference to surface flowing waters. However, surface still waters are subject to the rule stating that the owner of land is the owner of water ${ }^{15}$. Such circumstances have determined the need for a separate treatment of ownership in the Water Law.

12 B. Rakoczy, Wtasność wód w prawie polskim, Przegląd Prawa Ochrony Środowiska 2013, No. 1, p. 9-28; B. Rakoczy, Nabycie wtasności gruntu pokrytego wodami, Przegląd Prawa Ochrony Środowiska 2015, No. 1, p. 9-22.

13 The same conceptual model and assumption underlies the term of mining property for more details see e.g. B. Rakoczy, in: Prawo geologiczne i górnicze. Komentarz, B. Rakoczy (ed.), Warszawa 2015.

14 See e.g. J. Szachułowicz, Prawo wodne. Komentarz, Warszawa 2010, p. 60 et seq.; B. Rakoczy, in: Prawo wodne. Komentarz, B. Rakoczy (ed.), Warszawa 2013, p. 76 et seq.; M. Kałużny, Prawo wodne. Komentarz, Warszawa 2016, p. 87 et seq.

15 Also see K. Kowalski, Gospodarka nieruchomościami pokrytymi wodami ptynacymi, Wrocław 2010. 
In addition to the regulatory areas of the Water Law proposed by W. Radecki, issues related to regulations concerning flooding and draught should also be mentioned. These issues are not traditionally classified as water law issues. Rather, they are associated with natural disasters and states of emergency. However, de lege lata these issues are governed by the system of the Polish law, mainly in the Water Law.

Regulations governing floods and draught are mostly of protective nature but instead of referring to water they refer to other elements of nature, economy and finally to human life and health. However, what is meant in the context of draught is protection related to the lack of water, and in case of floods - protection against excessive and uncontrolled flow.

Irrespective of areas indicated by W. Radecki as regulated by the Water Law, issues of legal liability should be also given a separate treatment. In case of liability, either criminal or civil, or even administrative, the lawmaker has not developed new solutions that are characteristic of the Water Law only. It makes use of typical and traditional juridical structures. However, circumstances resulting in such liability are characteristic of the Water Law. It can be pointed out that the draft of the new Water Law legal liability is not a separate issue and sanctions are scattered throughout the draft act.

A separate issue to be analyzed in the context of the concept of the Water Law, representing a narrow understanding of water law, is the issue of public administration authorities that generally have powers characteristic of administration authorities, and powers regarding water management. The lawmaker did not give a positive opinion of such dualism, so the axiological priority adopted in the new Polish Water Law was the distinct separation of executive powers from powers related to water management. However, despite declarations, the postulate was not fully successful since the newly formed entity - a state-owned enterprise "Wody Polskie" (Polish Waters), despite its water management powers, would also have some executive powers.

The Water Law defines the powers and responsibilities of competent authorities only in matters related to protection and management of waters. Such authorities include the President of the National Water Management Board and directors of regional water management boards.

The Water Law also governs the use of water, the management of water and the protection of water. These regulations comprise a number of legal institutions. Regulations concerning planning play a very significant role in the Water Law. One of the most important decisions issued in the mode 
and according to the rules set out in the Water Law is the water legal permit.

To conclude the considerations regarding the concept of the Water Law, reference should be made to the interesting and inspiring considerations of J. Rotko, who investigates the role of this act in the system of environmental protection law. His considerations focus on both theoretical and pragmatic issues pointing out to relationships between respective legislative acts ${ }^{16}$.

However, the term "water law" is also used in a broader sense to which conceptual considerations apply. Without any doubt the concept of water law in a broad understanding covers issues already regulated by the Water Law itself. However, it turns out that issues related to waters, water management and protection go beyond the scope of the Water Law, and are also incorporated in other legal acts. Thus, analysing the concept of water law in a broad sense is fully justified.

Certain elements connected with the protection of waters, issues related to public supply of water and disposal of sewage, construction of flood control structures, issues related to prospecting and exploration, mostly extraction of minerals or groundwater, from the point of view of food safety are regulated otherwise than in the Water Law. Inland waters are also used for navigation purposes.

Issues related to protection of waters are also governed by the Act of 27 April 2001 Environmental Protection Law ${ }^{17}$. Pursuant to article 3 item 39 thereof „For the purposes of this Act:

9) environment shall mean the totality of natural elements, including those transformed as a result of man's activity, in particular the land surface, minerals, waters, air, landscapes, climate and other elements of biological variety, as well as interactions between such elements".

This definition clearly indicates that in the Polish law system waters are an element of natural environment and as such they are subject to protection. Thus, the concept of water law in a broad sense covers all norms governing the protection of waters as an element of natural environment. Article 97 of the Environmental Protection Law defines the protection of waters in general. It reads " 1 . The protection of waters shall consist of ensuring that their quality is as high as possible, including the maintenance of the

16 J. Rotko, Ustawa Prawo wodne w systemie prawa ochrony środowiska, in: Zagadnienia systemowe prawa ochrony środowiska, P. Korzeniowski (ed.), Łódź 2016, p. 101 et seq.

17 Journal of Laws of 2016 item 672, with further amendments. 


\section{Bartosz Rakoczy}

quantity of water at a level ensuring the protection of biological equilibrium, in particular by:

1) maintaining the quality of waters at a level higher than, or at least the same as, the level required by regulations;

2) taking measures to attain the quality of waters at, at least, the same level as required by regulations, where it has not been achieved.

2. The level of water quality shall be defined taking into account the quantities of substances and energies in waters and the capacity of aquatic ecosystems to function"18.

The analysis of a broader interpretation of water law leads to the conclusion that it is also regulated by the Act of 7 June 2001 on Public Supply of Water and Disposal of Sewage ${ }^{19}$.

The previous version of the Water $\mathrm{Law}^{20}$ of 24 October 1974 regulated the issues of water supply directly in articles $98-108$. Whereas, after it was repealed, the issues of public supply of water and public disposal of sewage have been regulated by a separate legislative act.

According to article 3 item 1 of the Act on Public Supply of Water and Public Disposal of Sewage, public supply of water and public disposal of sewage is an own task of the municipality. It means that the municipality carries out this task on its own behalf, at its own account, expense and risk.

According to article 2 item 21 of the Act on Public Supply of Water and Public Disposal of Sewage , public supply of water and public disposal of sewage mean activities consisting of taking in, treatment and supply of water by a water supply and sewage disposal company.

Water is supplied under a contract concluded by the consumer with the water supply and sewage disposal company ${ }^{21}$.

18 See e.g. K. Szuma, Zasady ocbrony wód w prawie polskim, in: Wybrane problemy prawa wodnego, B. Rakoczy (ed.), Warszawa 2013, p. 56 et seq.

19 Journal of Laws of 2015 item 139, with further amendments.

20 Journal of Laws item 230, with further amendments.

21 See e.g. J. Wiśniewski, Ustawa o zbiorowym zaopatrzeniu w wode $i$ zbiorowym odprowadzaniu ścieków, Bydgoszcz 2001; A. Rozwadowska - Palarz, H. Palarz, Wprowadzenie do ustawy o zbiorowym zaopatrzeniu w wodę i zbiorowym odprowadzaniu ścieków, Gdańsk 2002; K. Woryna, Zaopatrzenie nieruchomości w energie gaz i wodę. Poradnik odbiorcy, Warszawa 2003; G. Gałabuda, Zbiorowe zaopatrzenie w wodę i zbiorowe odprowadzanie ścieków. Praktyczny poradnik dla przedsiębiorstw wodociagowo - kanalizacyjnych, gmin i odbiorców, Zielona Góra 2003; M. Krzyszczak, Ustawa o zbiorowym zaopatrzeniu w wode $i$ zbiorowym odprowadzaniu ścieków. Komentarz dla praktyka z przepisami wykonawczymi i towarzyszacymi oraz wzorami umów, Warszawa 2005; B. Wierzbowski (ed.), Komentarz do ustawy z dnia 7 czerwca 2001 
Issues related to waters are also regulated by the Act of 9 June 2011 Geological and Mining Law ${ }^{22}$. However, pursuant to article 3 item 1 thereof "This Act shall not apply to:

1) the use of water to the extent regulated by separate regulations", but article 5 regulates issues related to curative waters, thermal waters and brines. Article 5 item 1 of the Geological and Mining Law indicates that "water is not defined as minerals with the exception of curative and thermal waters and brines" 23 .

The issue of waters is closely connected with the issue of flood protection. They are regulated by the Act of 16 September 2011 on Special Solutions for Removing the Effects of Flooding ${ }^{24}$. The Act of 8 July 2010 on Special Terms of Preparing Investments Related to Flood Protection Structures $^{25}$ is also very significant. This act sets out special terms and conditions of preparing investments related to flood protection structures, and it indicates competent authorities. Flood protection structures include flood channels, detention basins, barrages and storage tanks used for flood protection, dry flood control tanks, flood control embankments, storm gates, flood gates, breakwaters at the mouth of the river and marine flood protection structures - including facilities related in terms of functions".

Finally, issues related to waters are regulated by the Act of 25 August 2006 on Safety of Food and Nutrition ${ }^{26}$. However, in this case waters are interpreted in the light of nutritional safety ${ }^{27}$.

r. o zbiorowym zaopatrzeniu w wodę i zbiorowym odprowadzaniu ścieków, Bydgoszcz 2006; B. Dziadkiewicz, Zbiorowe zaopatrzenie w wodę i odprowadzanie ścieków. Komentarz do przepisów, umowy, taryfy, regulaminy, orzecznictwo, Warszawa 2011; P. Bojarski, W. Radecki, J. Rotko, Ustawa o zbiorowym zaopatrzeniu w wodę $i$ zbiorowym odprowadzaniu ścieków, Warszawa 2011; B. Rakoczy, Zbiorowe zaopatrzenie w wodę i zbiorowe odprowadzanie ścieków w praktyce przedsiębiorstw wodociagowo - kanalizacyjnych, Bydgoszcz 2012; M. Pawełczyk (ed.), Ustawa o zbiorowym zaopatrzeniu w wode $i$ zbiorowym odprowadzaniu ścieków. Komentarz, Warszawa 2014; B. Brynczak, K. Ubysz, Ustawa o zbiorowym zaopatrzeniu w wode i zbiorowym odprowadzaniu ścieków. Komentarz, Warszawa 2015.

22 Journal of Laws of 2015 item 196, with further amendments.

23 H. Schwarz, Prawo geologiczne i górnicze. Komentarz, vol. I, Wrocław 2013; B. Rakoczy (ed.), Prawo geologiczne i górnicze. Komentarz, Warszawa 2015.

24 Journal of Laws of 2016 item 825.

25 Journal of Laws of 2015 item 966, with further amendments.

26 Journal of Laws of 2015 item 594, with further amendments.

27 B. Korzycka - Iwanow, Prawo żywnościowe. Zarys prawa polskiego $i$ wspólnotowego, Warszawa 2007; A. Szymecka - Wesołowska (ed.), Bezpieczeństwo żywności i żywienia. Komentarz, Warszawa 2012. 


\section{Bartosz Rakoczy}

Also, reference must be made to article 1 item 1 of the Act of 21 December 2000 on Inland Navigation ${ }^{28}$, reading "this Act regulates matters pertaining to inland navigation on waterways considered navigable under the Water Law, hereinafter referred to as "inland waterways".

Thus, the problem is looked at in the light of food and nutrition instead of in the light of water management. However, it must be noted that pursuant to article 32 of the Water Law, "groundwaters, subject to article 33, are used mostly:

1) to supply people with water for human consumption and household purposes;

2) for the needs of producing foodstuffs and pharmaceuticals".

Thus, the use of groundwaters for household purposes and for the needs of foodstuffs production fully corresponds to the act on safety of food and nutrition. This is also evidenced in article 3 item 3 point 15 of the said act, which specifies that natural mineral water means "groundwater extracted from one or more natural or drilled holes, differing from water for human consumption with original chemical and microbiological purity and characteristic stable mineral composition and in specific cases also with properties of physiological significance having beneficial effect on human health".

The aforementioned considerations regarding the scope of water law in a broad understanding make it possible to indicate that the concept of the contemporary Polish water law covers water (waters) in different contexts. Sometimes water is the subject of regulations in the context of management. Another time, water is mentioned in the context of environmental protection as the element of such protection. In addition, water occurs in the context of household purposes as the fundamental component of food required to ensure human existence. Finally, water is regulated in the light of a threat constituted by its uncontrolled excess in the form of flood or its lack in the form of draught. Water is also considered the subject of legal relations, including the subject of property law.

Thus, it can be stated that the basis of the concept of the Polish water law is a diverse treatment of water issues. This diversity is so large that the problem of juridical treatment of water is handled by different areas of law that are often distant from one another. It is enough to indicate that

28 Journal of Laws of 2013 item 1458, with further amendments. 
water issues are of interest to both civil and administrative law experts and specialists dealing with environmental protection law. It is also of interest to researchers investigating the law of local government and municipal economy. Finally, these issues are investigated by experts in food law.

However, these very distinct aspects of legal regulations concerning waters can be combined into a single area and referred to as water law. Concurrently, water law understood in such terms meets all criteria to be classified as a comprehensive branch of law. Reference literature mentions certain criteria that make it possible or impossible to classify a specific area of legal regulations as a comprehensive branch of law, whereas the existence of an autonomous subject of this regulation is considered a fundamental criterion. With reference to water law there is no doubt that water is an autonomous subject of regulations and, as a consequence, an autonomous legal interest.

So, in general, which issues constitute water law in a broad sense and, as a consequence, which elements constitute the concept (vision) of the Polish water law? Without any doubt, the highest level of generality should be assigned to management of waters, their protection and ownership. Such priorities are created by the lawmaker itself in the above-quoted article 1item 1 and 1a of the Water Law.

The management of waters covers areas of economic use of waters and existential use of waters. The first case refers to the use of waters for economic purposes. The other case refers to using it for household purposes related to human existence. Water management also includes issues of public supply of water and the use of waters in the context of safety of food and nutrition. Water management also covers the use of waters for navigation purposes.

In turn, the protection of waters as an element of natural environment covers all regulations concerning the environmental aspect. In this case, waters are treated as a natural element that must be protected.

The above-analysed issue of ownership of waters should be regarded a significant element of the concept of water law.

The problem of water management is also related to protection against flood and draught, and the relation of water law with geological and mining law. In this case, waters are not an autonomous legal interest subject to protection. However, they play a significant role in the regulations. In case of floods, it is the excess of water and its uncontrolled flow. On the other hand, in case of draught it is the lack of the adequate level of water. Here, the problem is an insufficient level of water and not water itself. Finally, 


\section{Bartosz Rakoczy}

in the light of geology and mining, the subject of the regulations are mine waters, curative waters, thermal waters and brines.

To sum up, it must be indicated that the analysis of the concept of the Polish water law covers both the broad and narrow treatment of this term. In a narrow sense, water law covers the Water Law only. On the other hand, in a broad sense, water law also covers other legislative acts governing water issues. In the other case, it is clear that the adopted concept is based on the diverse treatment of water issues. An element combining these different positions is water as an autonomous legal interest. Despite changes in the Polish water law and proceeding of the act, it seems that the hitherto developed concept of water law alone in a broad sense will not change.

\section{Bibliography}

Bezpieczeństwo żywności i żywienia. Komentarz, A. Szymecka - Wesołowska (ed.), Warszawa 2012.

Bojarski P., Radecki W., Rotko J., Ustawa o zbiorowym zaopatrzeniu w wode i zbiorowym odprowadzaniu scieków, Warszawa 2011.

Brynczak B., Ubysz K., Ustawa o zbiorowym zaopatrzeniu w wode $i$ zbiorowym odprowadzaniu ścieków. Komentarz, Warszawa 2015.

Dziadkiewicz B., Zbiorowe zaopatrzenie w wodę i odprowadzanie ściekórw. Komentarz do przepisów, umowy, taryfy, regulaminy, orzecznictwo, Warszawa 2011.

Gałabuda G., Zbiorowe zaopatrzenie w wodę $i$ zbiorowe odprowadzanie ścieków. Praktyczny poradnik dla przedsiębiorstw wodociagowo - kanalizacyjnych, gmin i odbiorców, Zielona Góra 2003.

Habuda A. (ed.), Polskie prawo leśne, Warszawa 2016.

Kałużny M., Prawo wodne. Komentarz, Warszawa 2016.

Komentarz do ustawy z dnia 7 czerwca 2001 r. o zbiorowym zaopatrzeniu w wode i zbiorowym odprowadzaniu ścieków, B. Wierzbowski (ed.), Bydgoszcz 2006.

Korzycka - Iwanow B., Prawo żywnościowe. Zarys prawa polskiego $i$ wspólnotowego, Warszawa 2007.

Kowalski K., Gospodarka nieruchomościami pokrytymi wodami ptynacymi, Wrocław 2010.

Krzyszczak M., Ustawa o zbiorowym zaopatrzeniu w wode $i$ zbiorowym odprowadzaniu ścieków. Komentarz dla praktyka z przepisami wykonawczymi i towarzyszacymi oraz wzorami umów, Warszawa 2005.

Paczuski R., Ochrona środowiska. Zarys wyktadu, Bydgoszcz 2008.

Prawo geologiczne i górnicze. Komentarz, B. Rakoczy (ed.), Warszawa 2015.

Prawo wodne. Komentarz, B. Rakoczy (ed.), Warszawa 2013. 
Prawo wodne. Komentarz, J. Rotko (ed.), Wrocław 2002.

Rakoczy B., Nabycie wtasności gruntu pokrytego wodami, Przegląd Prawa Ochrony Środowiska 2015, No. 1.

Rakoczy B., Wtasnośc wód w prawie polskim, Przegląd Prawa Ochrony Środowiska 2013, No. 1.

Rakoczy B., Wprowadzenie do prawa wodnego, in: Wybrane problemy prawa wodnego, B. Rakoczy (ed.), Warszawa 2011.

Rakoczy B., Zbiorowe zaopatrzenie w wodę $i$ zbiorowe odprowadzanie ścieków w praktyce przedsiębiorstw wodociagowo - kanalizacyjnych, Bydgoszcz 2012.

Rotko J., Podstawy prawne gospodarki wodnej, Wrocław 2006.

Rotko J., Ramowa dyrektywa wodna. Analiza prawna, Poznań 2013.

Rotko J., Ustawa Prawo wodne w systemie prawa ochrony środowiska, in: Zagadnienia systemowe prawa ochrony środowiska, P. Korzeniowski (ed.), Łódź 2016.

Rozwadowska - Palarz A., Palarz H., Wprowadzenie do ustawy o zbiorowym zaopatrzeniu w wodę i zbiorowym odprowadzaniu ścieków, Gdańsk 2002.

Schwarz H., Prawo geologiczne i górnicze. Komentarz, vol. I, Wrocław 2013; B. Rakoczy (ed.), Prawo geologiczne i górnicze. Komentarz, Warszawa 2015.

Szachułowicz J., Prawo wodne. Komentarz, Warszawa 2010.

Szuma K., Prawo wodne w systemie prawa ochrony środowiska, part 1 - Prawo i Środowisko 2011, No. 1, part 2 - Prawo i Środowisko 2011, No. 2.

Szuma K., Zasady ochrony wód w prawie polskim, in: Wybrane problemy prawa wodnego, B. Rakoczy (ed.), Warszawa 2013.

Ustawa o zbiorowym zaopatrzeniu w wode $i$ zbiorowym odprowadzaniu ścieków. Komentarz, M. Pawełczyk (ed.), Warszawa 2014.

Wielka Encyklopedia Prawa, vol. VI Prawo ochrony środowiska, Górski M., Stelmasiak J. (eds), Warszawa 2014.

Wiśniewski J., Ustawa o zbiorowym zaopatrzeniu w wodę $i$ zbiorowym odprowadzaniu ściekórw, Bydgoszcz 2001.

Woryna K., Zaopatrzenie nieruchomości w energie gaz $i$ wodę. Poradnik odbiorcy, Warszawa 2003.

\section{Email:}

kpos@umk.pl 